\title{
Machine Guns with Cavalry
}

\section{Captain W. Anstruther Thomson}

To cite this article: Captain W. Anstruther Thomson (1894) Machine Guns with Cavalry, Royal United Services Institution. Journal, 38:196, 617-639, DOI: 10.1080/03071849109418587

To link to this article: http://dx.doi.org/10.1080/03071849109418587

$$
\text { 曲 Published online: } 11 \text { Sep } 2009 .
$$

$\sqrt{4}$ Submit your article to this journal $\pi$


Fridny, February 23, 1894.

Liedt.-Gexeral J. KEITH FRASER, in the Chair.

\section{DIACHINE GULS WITH CAVALRY.}

By Captain W. Asstretmer Thoysos, Rogal Horse Guards.

I. Introduction.

II. Idstone Mancurres, \&c.

III. MIntéricl-

A. Transport.

B. Ammunition.

C. Range.

D. Sights.

F. Shicld.

IV. Personnel-

a. Detacliment.

ק. Scouts.

$\gamma$. Escort.

T. Forcign Progress.

TI. Conclusion.

\section{Istroduction.}

IT has sometimes been suggested that machine-guns should form part of a battery of artillers, but this idea has wisely been ignored, for although they might sometimes be so emplojed, especially as a safegnard against caralry attack, the trac rôle of the mnchine-gun is in independent action.

The value of machine-gans for purposes of defenec is generally almitted among nations, but, as our cavalry drill book so abls points out, these weapons can do far more than this, and there is now no doubt that, in taking part in a rigorous offence, reliable machine-guns will prove invaluable.

Let them push; forward with the first line, if possible, wherever they may find cover, and dash out, as opportunity occurs, and take the enemy by surprise. $A$ bedge, a liasrick, a cottnge, a clump of trees, or even a heap of stones, will often furnish a hiding place for the occasion.

The gun presents so small a target, it is so casily concenled, it is so quick, so mobile, and so deadly, that when properly handled it should rarely be captured or put out of action. Now and again, no doubt, 
one will be lost, but these dogs bite, and men and horses will think twico before attacking them, except under the most favourable circumstances; and if they servo their purpose it may pay to sacrifice them. It is casy to render them useless to the enemy : to carry away or hide the lock, or feed block, to jnmb the bore, or to knock off the sight, would be the work of a moment. It is eren possible to unhiteh the gun itself and carry it off in one's arms for a few lhundred yards, or otherwise to disable it; but a clean pair of hecls will generally obvinte that necessity.

Except when it is desirable to hide it, the caralry machine-gun is of no use galloping behind the centre squadron of a regiment; it should be array on the flank, where it can best get a chance of manceuvring with offect; it is only in the way as a surrefle.

The gun commander must keep his eyes open, he must watch the cnemy, and watch the ground, and watch his own force too. He must kcep his line of retreat secure, if possible, and not allow himself to bo taken in flank, or rear, or get too far away from succour. He must choose his positions well, and decide quick and travel quick, for it is one thing to select a position, and quite another thing to get therc.

He must crer be pushing on, taking every short cut and adrantage possible.

IIe must always be "there," but never in the way.

Caralry michinc-guns should scize erers chance, not only against caralry but against the other arms, especially artillery; to creep along a hedge, to get within range without exposure, to fire at guns, horses, and cscort, at abont $1,000 \mathrm{sds}$., will be a right task for a single gun, and if war has any likevess to maucurres such golden opportunities will constantly recur.

There would be no waiting for an umpire then, and few would be the arguments urged against the inachine-gun when it had played for half a minute at a fair target within that range.

At the same tine it must be remembered that one well-directed shell will demolish the machine-gun, and it is only where sufficient corer is forthcoming that this can safely be done.

'To illnstrate the subject, I will now ask you to follow a machine: gun through the Idstone Manouvres of 1893, showing tho opportnnities that may arise for such a weapon with caralry in the field.

\section{IustoNe Maxcurres.}

Batlle of 4 th September.

\section{(Map 1.)}

Position 1.-Our carally division was formed up south of Bishopstone Downs, north-cast of Russley Park, while the enemy's advancing infantry approached to within 1,000 yds. of our entrencbments on Idstone Fowns. 
Tho caraly division swept round and charged the infantry in flank, who at once formed groupe, prescnting a perfect target for the Maxim gun, as well as the artillery and infautry, on the hill overlooking them. At about the same time a battery of the enemy's horse artillery, appearing at the west of Swinley Copse, camo under Mraxim firo at 1,000 $\mathrm{gds}$., and would have been destroyed.

Ammunition.-Tho 3,500 rounds laid down to be carried on the Maxim carriage would hare sufficed for all this.

Remarlis. $-\Lambda$ squadron of our hassars was sent round to the right, east of $A$ shdown Park, and took a battery in rear.

Two squadrons were sent to the left to threaten the enemy's flank, but their attack was inefectual.

Machine-guns with both these partics would have been of service.

\section{Latlle of 5th September.-First Plase.}

Position 1.-Our brigade formed up under lognam Cluinp until the order was given to attack the advancing enemy.

When our artillery took up a position to tho south, on Bailey Hill, and our cavalry trotted north under cover of Kingston Down, the Maxim gun on their right rear.

Position 2.-Hearing the enems's artillery firing to our right we galloped our gun to the brow, and opened fire at a range of $800 \mathrm{yds}$, taking them in enfilade.

The enemy's Nordenfelt, concealed at Half MIoon Corert, turnine its attention on us, we had to retire bejond the brow, but by this time the enems's guns had retreated.

Here we were glad of our shield and our power of retarning ten shots for every one of the Nordenfelt.

Position 3.- We then hurried after onr caralry, and arriced at the nick of time to catch two squadrons of the enemy in flank as they wheeled to the north to face the charge of one of our regiments round the old Warren Wood.

Here the battlo was stopped.

Ammetnition.-Ammunition would have sufficed.

\section{Battle of 5th September.-Second Phase.}

The brigade halted ander cover of Hinton Down.

Position 1.-The Maxim hiding in the fir-tree strip to guard the right and front, while the artillery took up a position on the left.

Position 2.-The enemy's gans appearing at the clump nortl-west of Rassley Park, we galloped to the tumulus on our left front, and there hid.

The hostile cavalys now showed itself north of Russley Parb.

Position 3.-One squadron, clarging to the south, came ander Mlaxim fire at $600 \mathrm{yds}$, the gun galloping out and back so rapidly that the enemy's artillery would have had no time to take aim at it, they were besides busily engaged in a duel with our artillery.

Positions 4 and 5. - The main body of the enemy next advanced in VOL. XXX7III. 
column, the Mraxim playing on them from 1,200 to $400 \mathrm{gds}$. 'They charged our caralry and artillery on the north side of the tumulus, but ignored the $)$ Iaxim gun, which now poured a hail of lead into their flank at 200 sds.

Position 6.- The gun, of course, ran great risk of capture, and in tho end a squadron surrounded it, but a moment later cease fire was sounded. The end attainable was worth the risk wo ran.

Ammanition.-The ammunition on the gan would lave been expended, bat our reserre supply rould havo been close at hand.

Scouts. - On this liny we had but one scout, and for some time not oven one, as his horse fell head orer heels, clipping a piece out of the gun wheel with his hind shoe.

We might casily havo been surprised at the tumulns, and we felt most severely the want of proper scouts. Good men, well trined and well mounted are absolutely necessary to a machine-gun with cavalry.

\section{Battle of Gth September.}

From Old Warren, where wo saw sone of the enemy's sconts and a squadron of their hussars about a mile to the north-west, we galloped through Knighton Bushes on to Welibottom Down.

Our caralry and gans halting just below the ridgo under cover from the encmy's artillers, some $1,800 \mathrm{jds}$. to the north-east, who now opened fire on the cavalyy whom they land just scen.

'The Masim, under cover of the ridge some $400 \mathrm{yds}$. to the loft, opened fire on the guus and cscort for a fow seconds at 1,800 yds., again withdiawing below the crest to guard our left and front from surprise.

Our brigade then wheeled to tho left, trotting north towaris Uffingtou Castle, under corer of Woodstone Down.

Our artillery taking up a position to the north of the clump, the Mraxim on their right behind it.

Obserring a squadron of the enemy's liussars halted west of the strip, we ran out and opened fire on them at 800 sds.

They at once took corer on the south side of the strip, while we mored so as to corer them if they emerged.

This they did, and were under Mlaxim fire for the space of $800 \mathrm{Jds}$., within easy range.

Our caralry had meanwhile charged the rest of the brigade which were drawn up to the right of their enemy's guns, and a furious combat was raging south of Knighton Warren Farn.

The above-mentioned squadron of hussars, although theoretically slain by Maxins fire, did ycoman service to their side by taking our men in rear.

$\Lambda$ s soon as they were gone wo galloped to Knighton Warren Farm, taking corer under a liayick, cauglut the cncuy's artiller's as they were limbering up at $800 \mathrm{~s}$ ds.

The battle then ceased.

The pesition behind the clump was most faromable for the Mraxim, and had it not been there, the squadron from behind the strip coula 
have done all the execution they got credit for, nud more than this had they boldly charged our guns instead of halting where they did it is not impossible that they night have rolled the escort up and taken our guns in rear; a machine-gun on tho flank will sare many a day.

Ammunition would havo sufficed, and reservo supply could haro been at liand.

\section{Battle of 1lth Septemibr.}

The Maxim took up a position behind a ragged hedge at the cross roads south-rrest of Uffington Camp.

A few moments later wo found a contact squadron of our hussars retiring before a superior force of the enemy's caralry. Allowing onr men to approach to nbout 300 sds. wo darted from our corer and fired down the road. Our squadron drawing off to tho east as soon as they obserred us.

'l'he encmy retired.

The Mraxim, supported by the contact squadron, adranced, and finding a squadron of the cnemy halted orer the spur of Woodstone Down, greeted them with a rattling fire at $250 \mathrm{yds}$., causing them to whecl about and retiro at a smart pace.

Seeing the enemy's guns on Tower Hill we galloped into the hollow erst of Pingooso Corert, the Mraxim crecping out of sight to the end of the strip and opening on them at 1,000 yds.; our infantry meanwhilo adrancing on either side.

Perceiving a lot of dust over the rising ground, about 1,000 rds. south-cast, wo galloped to the brow anticipating a charge from the enemy's cavaliy on the left flank of our line, but only found a squadron.

We opened fire at 800 sds., and caused them to retreat to Knighton Bushes; wo now returned to tho south of Pingoose Covert, nud from thence galloped to Compton Botton; ; here the enemy's squadron again came under the Jaxim's fire, and two of their troops were put out of nction.

Our infanty's turning at Compton Bottom attacked the enemy's right flank, and seeing a goot place among the old trees $200 \mathrm{gds}$. to the west, we galloped there and poured a murderous fire on the limbering guns and retreating infantry, who now had to leavo their shelter trenclies.

The contact squadron had by this time left us. Here we remained until Kuigliton Bushes were clcar, and then galloped through then. checking at the further end till a scout reported all clear boyond We then emerged, and seeing somo squadrons of the encmy halted on the hill $1,000 \mathrm{jds}$. to the south, wo opened fire and they retired.

Wo were now put out of action, having mistaken the enomy's Rifles for the Cameroninus, who were on our side, a mistake which wonld hare cutailed our speeds demolition.

After an enforced halt of 10 minutes we made a fresh start, and climbed on to Kingston Down. Kecping under corcr, as far as possible, till we reached the shelter of the Rubbing Honse; here 
finding the enemy's infantry with a Nordenfelt in front of us, we opeued fire at 400 yds.

Our infantry advancing as the encmy retired, at length reached the foot of the Down when the guards were attacked by a squadron, and a fer moments later the whole line was cluarged by the enemy's carally brigade.

The Maxim nnd guns on the slope of the hill playing on them from 1,000 to $400 \mathrm{sds}$. distance.

Few could hare cscaped the combined fire of artillers, infantry, and machine guns.

Our force then advanced across the valley to attack the guns on Bailey Ilill, the Mlaxim hiding under cover of Fognnm Clamp till a fresh opportunity should arise.

Here the battle censed.

Ammunition would bave been a difficulty in this battle, as we should hare expended our allowance many times over, but there was wothing to prevent a fresh supply following in rear of our armip.

Had the contact squadron remained with us we should probably have been enred the blander that put us out of action, aud the Rifles would hare afforded a grand opportunity for a cavalry charge from tlec wood, and an excellent target for tho Maxim when thes formed square.

\section{Battle of $12 t h$ Septcmler.}

We were escorting a conroy, proceeding to Lambourne, tiat the Ichnield way and south to tho west of Ashdown.

Our advance guard, a squadron of hussars, accompanied by the Mnxim, pushed forward along the Icknield way to within $400 \mathrm{yds}$. of Ashbury Folly. When a squadion of the enemy was found adrancing towards them.

The Maxim at once galloped forward and opened fire at $400 \mathrm{gds}$, npon which the enemy took shelter under souse farm huildings ou their left.

We then obserred from the cover of the hedge, the whole brigade of the enemy's caralry adrancing at a walk $800 \mathrm{yds}$. to our left. We at once opened fire and plajed npon them until they were out of siglit, bnt no notice was taken of us.

The hostile guns now appearing on Tower Hill we retired to a position on the right of our artillery, where we found cover under a hedge and bank alongside of the mounted infantry.

Our caralry was in rear of the clump and the convoy half a mile to the north under cover of the hill.

The enemy's cavalry charged our guns under fire of the mounted infantry, and the Maxim, from 1200 to 300 yds., and were then met by our caralry with the result that some of the enemy were put out of action.

Our cavalry then mored to the left to attack the guns on Tower Hill. 'l'he Mlaxim dashing forward to Odstone Barn to support thew, upened fire on the enemy's guns at 1,000 jds. Our nounted infantry following in reserre. 
We then galloped to Down Folley, firing again on the guns at 600 jds.

Thus ended the first phase of the battle.

The conros proceeded along the Icknield was, tarning to the south by the track leading to Red Barn. The Maxim being in rear, expecting an attack from that quarter. As we left the Icknicld was the enemp's guns opened on us, bnt on reaching the corer of Red Barn, the Maxim came into action, and returned their fire at $800 \mathrm{y}$ ds.

'Tro squadrons of the enenyy's hussars threatened our left from the north of Hayley Wood. To opened fire on them, but obserring two of our regiments wheel about unseen by them, we tried to entice them on, trotting a littlo way and halting, pretending to be in trouble; thinking us au easy prey, they charged round the wood and were caught by our two regiments in front, and the mounted infantry at led Barn in the rear. They were put out of action.

The attack in rear having been disposed of, the Maxim trotted on in advance, expectiug work in front.

Arrived at King Alfred's Camp. We applicd for a field troop as escort to help us to secure the road between $A$ shdown and $U_{p p e r}$ Wood.

Instead of a troop, two sqnadrons came with us, and the gun sccured the road, but a rumour of an enemy's squadron over the hill to the south took the two squadrons awas and the Maxim unwillingly accompanied them.

There was no enemy there and as we hurried back we sam the dust rising on the road we hnd left, proving that we were too late. The enemy's brigade now emerged.

Hoping that they would attack the convoy and that we should get them in rear we remained out of sight orer the brow of the hill, but thes discorered and two squadrons attacked us, forming a splendid target for the Maxim gun as they charged op the hill. We shonld hare demolished a lot of them, although we were lost ourselves.

We were put out : of action with a ficld troop of the enemy slain by the Maxim gun.

The ammunition on the gan would hare been expended, in the first phase of the battle, but reserve supplies would hare accompanied the convos.

\section{Baltle of 13 th Septemiler.}

drriving at the rendezrous at Fognam Clump we found the enemy holding Idstone Down. Our infantry adranced to tho attack on both sides of Bottley Copse. Our artillery opening fire from Bailey Hill, our cavalry remaining under cover of Upper Wood.

The Maxim galloped to a position under corer at the east of Bottley Copse opening fire on two of the cuemy's squadrons on the move at about 500 sds.

On our infantry machine-guns coming to this position, we mored lest we should attract artillery fire, and from the wall on the west of the copse opened fire on the enemy's infantry at $800 \mathrm{yds}$. 
So soon as the hill was clear wo galloped to the brow and caught the last line of retiring infantr's in enfilade at $300 \mathrm{Jds}$. Krepping the gan as much as possible under the hill, the mazzle only showing.

Finding farther adrance on the glacis impossible, we galloped under cover of the Down to Threo Barrows, where we found shelter, and fircl on the cnemy at 1,000 $\mathrm{gds}$.

We next advanced to a tumulus 500 gds. rest of Harley Bushes, firing at retreating infantry and a squadron of cavalry at $600 \mathrm{yds}$., and then galloping on to One o'Clock Hill Clump wo got a good chance at the infantry, on 'T'ro o'Clock Hill, at 900 Jels.

Finally, on to Tro o'Clock Hill, when our adrance was stopped, to allow the hard pressed foc to retire to Iamby Down.

The ground did not adnit of further advance nntil Lamby Down was clear, bat we had obsersed a squadron of cavalry on the right flank and they now were halted at Starreall Farm, we were about to make an attack on them when cense fire sounded.

Here wo were drawn into the infantry fight right awny from ons. caralyy brigade, who crentually had a combat of its orn on Hinton Down.

Hut wo had left them halted at Upper. Wood and had becn hard at work the whole time. Unless specially ordered, it would hare been folly to remain idle, while there was good work and good cover for us at the front.

This day showed me how uscfal fast machine-guns might be in an infantry fight on suitable ground, kecping under cover, galloping overswhere, popping up at nnexpected places, and often securing the flank against nttack from cavalry.

Ammanition would hare been expended many times orer, but reserve supplies could haro followed us in rear.

In an infantry fight I believe there would often be time to gallop back and refill the ammunition boxes, but perhaps this mancourre would be attribated to cowardice. TVith caralry, howerer, this could seldom bo done.

It was on this day that the enemy's earalry Nordenfelt was captured by three or four of our bussars.

\section{Battle of 14th. Septembci.}

Wo were to defend the renr of an army retiring on Uffington Castle.

An infantry and artillery fight was taking place to the west, for the possession of Idstone Hill; onr caralrs brignde was in reserve under cover of Red Barn; our horse artillery, with a mounted infantry cscort, at King Alfred's Camp, while a party of mounted infantr'y was sent to Swinley Copse, to line the hedge to the rest of them.

The Maxim halted bebind a convenient hajstack till affairs developed.

After a long wait, we observed that a party of the enemy's hosse, about a squadron and a half, had approached to Starvenll Firm, and were balted there, nnder corer from our guns. We at once galloped 
to the best position we could find, and opened fire on them at l,200 yds., and then, as this position was exposed to the eucmy's shells, wo took corcr at King Alfred's Camp.

The enemy's party then energed from Starreall Farm, making a sweeping clargo to the north-cast presamably with a view of taking our guns.

The Mraxim galloped ont from belind King Alfred's Camp, opening on them, from 800 to $400 \mathrm{yds}$.

'The mounted infantry at the same time giring them a snccession of rolleys; they sought shelter at Parsonagehill Barn, but were pnt out of action. Cense fire then sounded.

This was the only picce of caralry work that took place on that lhy, besond a few mounted infantry being put ont of action; and it was tho last affair in which the Marim took part.

I mas add that during these manocurres we had, on one occasion, six men hanling on to ropes to keep the gron from capsizing, and irequently we had three men pulling behind, as a drag down hill.

The gun never had to turn back from an obstaclo during mancuvres, though of conrse wo had to choose onr places, and sometimes take the horses ont to save the strain on our liarness.

The samo horses camo out ercry day, and did a 37-mile march to wind up with without being sick or sorry.

\section{The Gun on Service.}

The following details from Matabililand $I$ lare learned from an eye-witness:- It the battle of lst November, which took place in the afternoon, tho MIntabilis charged to withir $140 \mathrm{yds}$. distance of tho laager, when tho rush was stopped by Maxim fire.

At the battle of the Shangani, 24th October, which was fonght in the dusk, the nearest natives killed were but 50 yds. from the Miaxim.

Most of the enemy were killed by the machine guns, their fire being stendier than that of tho rifles, and the range easier to discern. T'he killed were mostly strnck by bullets in two or threc places.

The gans were fired by cool, experienced men, the late Captain Lendy and Lieutenant Llewellyn (late R.N.) were the firers of two of them.

To this point I attach great importance, the firer must be an intelligent and steady man, who knows how to handlo his meapon, and what to do if it jams, and the best means of preventing this casualty. Such a mun is well worth a shield to protect him.

Liontenant Llewellyn's gun was driven in a carriago drawn by four mules. Captain Isendy's gun was carricd on horseback; he bronght his gun into action in 60 seconds.

In the Victoria Column the machine-gans were on carts drawn by six horses, and witl drivers.

A pack saddle for bush work próved a tremendons saring.

I have hero a letter from an officer who took part in the Matabili campaign, extracts of which may be of interest:-

"With regard to tho Masims, I am perfectly certain that the best 
method of cerrying them is on galloping carriages with a tripod in the net behind, so that they can bo moved to any point at once.

"Eren with infantry, I should havo them on galloping carriages; they are on a higher lerel, and command a greater frontal fire, and can be brought to any point at once, and thes could be left on an eminence to fire orer the hends of adrancing infantry, and then brought up again at a gallop.

"You should, I think, hare two Mrnxims on a giren face, so that there is no cessation of fire whilst belts are being chunged or from other causes.

"Thes can be used up to a rery long range, and were used by us up to $2,000 \mathrm{jds}$. with deadly effect upon natires retreating along the sky-line, the distance being found by firing tro single sliells from a 7-pr.

"Thes are equally deadls at close quarters, and did grcat exccution at 400 and 500 yds., and eren closer, on any body of natires attempting to mass.

"In fact, it was perfectly impossible for them to do so, no matter what brarery they might have shown.

"At the same time jou must remember we were also under a hot fire from the enemy.

"I deprecate the large detachment we have in the service; let the men be trained by all means, but three is ample about the gun.

"The gun should be left to tlie man firing it. Do not let him be harassed by orders. Iret him use his ewn common sense; the gun will be worked better and the men hare more contidence.

- "We had no one about the guns except three men, and it was extraordinary the way they worked them, censing fire when thes saw that it had been effectual and turning it on to another point where it was most required.

- "Each man was thoroughly up in the mechanism of the guv, aud could put it to rights whaterer happened.

"We had spare locks and crergthing reads, but they nerer jammed once.

"We placed the guns a little outside the langer, with \& circle of thorn-bush, about $15 \mathrm{ft}$. broad, ronnd them, so that by slewing round the trail you could flank any side of the laager; it was, in fact, a

square fort with a lunette at each corner.

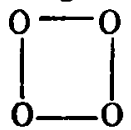

"The moral effect of the Maxim I consiler great, the continuous firing which can be heard above everything, gires the grentest confidence to the men, and you can imagine the effect on troops of a hail of bullets pouring on to them without cessation.

"I think it advisable not to reserve the fire of Maxins until the enemy is at close quarters, but begin at say 1,500 sds.

"The effect rould be rery striking on advancing troops, especially if you lept tho gun working on tho traverse. The great thing about them is the continuous stream of bullets. 
"Sach an amount of lead can be put in during the most rapid advance that it is my own belief not eren tho best troops in the world could adrance against three or four Maxims well served."

I may add that Sir John Willoughbs, mho was Chief of the Staff, mentions in his despatches that the Maxims did good service at 2,000 yds., and $I$ have it on the authority of the Higli Commissioner, Sir Henry Loch, that they would never hare been able to keep the Matabili at a distance withont tho Maxim guns.

Mr. Selous, who has just returned, bears witness, also, to the immense atility of the caralrs machine-guns in Mlatabililand.

\section{Mitfiriet.}

\section{A. Transport.}

Having followed the gun in mancuvres and in action, let us now turn our attention to the rexed questions of matériel and personnel, upon which such raried opinions are held, aroiding, with your permission, uninteresting nechanical details.

From experience at the above mancurres and elsewhere, I am led to ccrtain conclusions which I will, with all due deference, put before jou.

Transport of the Gun.-In the paper read in this theatre bs Captain Benson, R.A., in November, 1887, and in that read at Aldershot b5 Captain Stone, R.A., in Juls, 1888, and in the discussions which followed, this subject was well threshed out; but, although five years have clapsed since then, very little las been practically clone tbirardş the solution of the duestion, which I maintain can only be solred by practice in the field. Personally I would like to see experiments tricd with a four-whecled buggy on hickory whecls, somewhat of tho buckboard type. It is important to keep the carriage from being top-heary, and I should mount the gan with a small shicld to protect the firer close to the rear axle, so that it conld be fired with the least possible vibration, with the borses in, if necessnry, though they shonld be taken out whenever it is safe to do so; bnt in carnlry work this can seldom be done, for though it takes but a few seconds to take them out or put them in, it is the seconds that make all the difference.

While on this subject I would like to point oul a carringe designed by the Maxim-Nordenfelt Company for a 3-lb. Q.F. gun firing 15 aimed shots a minute.

The horses to be drisen three abreast like the Russian troikn.

I cannot here cnter into the question of quick-firing guus with cavalis, it is beyond the sphere of this lecture, but $I$ think that $I$ may safely say that these aro the weapons most to be dreaded by machine guns on serrice.

I hare here two cartridges-common shell and shrapnel-designed for the 3.lb., and carreing 45 bullets, case shot containing 108 bullets, but I think u larger calibre, such as a 6 -lb., would be far prefernble.

But to return to our subject, I mnst sas that from personal ex- 
perience I have great respect for a cart of the buckboard type, having been taken over places in them, in the Australian bush, that I had decmed quite impassable; and I expect that thero are many officers here who, having travelled in Awerica and Australia and elsewhere, know how much can be dono over rough conintry, in a four-whecled bnggy henvily laden, and not alwass with the best broken horses. At the same time it must be remembered that whecls will not go ercrswhere, and I am strongly in farour of having a pack saddle and tripod handy in caso of need.

The Cape Mounted Rifles have adopted this snggestion, and a pack saddle is to accompany every Maxim.

The saddle they hare adopted is Captain Newbrargh Stewart's, which is fashioned with a hinged tree, somewhat on a similar principle to the Austrian saddle, which has come as a blessing to caraly'f, and was introduced into this country by General Keith Fraser.

Another saddle which appears to me well suited to the purpose is that inrented by General Bogle; it lass the great advantage of conntcrneting the dead weight of the lond by means of $\Omega$ kiud of cradle and four springs, the weight being distributed over tho whole horse's back, instead of having all tho pressure on the top.

I hare seen a horse with Gardiner gun tripod and 300 ronnds of ammunition jump $4 \mathrm{ft}$. high in this saddle, and it takes but 10 seconds to come into action and about 20 to replace the gun on horseback.

It is adapted for carrying ammunition and other baggago as well.

Thingle the courtesy of the above-named gentlemen, both these saddles are here for jour inspection.

At least one ammunition horse would, of course, accompany every pack saddlo gnn with a load of 2,000 rounds.

Light entrenching tools should always bo carricd with the gun, whether on horseback or on whecls; $n$ few strokes with axe or spndo will often enable tho carriago to cross an obstacle that otherwise would be impossible, and a hasty entrenchment might sometimes bo of nse.

As regards harness, I beliere that we might get some usefnl hints from the fire brigades of different countries, but the harness invented by Major Baden-Powell, and adopted by the Gorernment, enables the horses to bo taken out or pat into the carringe in 10 scconds, and this will be liard to beat.

\section{B. Ammunition.}

It is laid down that the MInxim gun should carry 3,500 rounds M.II. bare on the carriage, and 7,200 in the ammunition cart; the whole amount should, of course, bo carried in belts, while the Noxdenfelt carries 2,000 in boxes. 'The introduction of the 0-303 bore will euable us to carry abont half as much again.

With machine gans it is of the utrnost moment that reservo ammunition should bo forthcoming when required. The cxpenditure is so cnormous and so rapid that unless fresh supplies are at hand the 
gans may find themselves out of action at the vers time when ther are most required.

The amount of ammunition to bo expended during the fight is a matter for carcfal judginent and anxious thought.

It can only be solved in the field; and no amount of theory will avail, unless the gun commander can keep his wits abont him and his reserve ammunition at haud. The amount of ammunition laid down for prnctico is quite inaclequate. An annual nllownnce of 200 ball and 300 blank for a gun that can fire 600 shots a minute, does not admit of a fair training for either men or horses.

Smokeless powder, so long as it is satisfactory and does not destroy the barrel, is all in farour of machine guns.

We will see our target withont being blinled with smoko or our position being rerealed by that cause.

The cordito 0.303 bore has not so far prored satisfactory in the Maxim gan, but the powders used abroad appear to answer, and I look on the remedy of these defects as only a matter of time.

\section{Range.}

This is a most important subject, and one to be thoroughly considered.

At $1,000 \mathrm{yds}$. it is possible to put r.carly every shot on a 12 -ft. target, the averago being 90 . hits out of 100 shots on $a 6 \times 8$-ft. target.

At the same target at 2,000 yds. the arerage is 15 per cent, but cren this would admit of somo 100 hits a minute, and at a squadron $9 \mathrm{ft}$. high by 50 wide tho pereentage would be much greater.

At 1,800 to 2,000 5ds. the Mraxim did good service in Mashonaland, and proved itself effective bejond thin range.

At distances within $1,000 \mathrm{yds}$., in the hands of expert and steady marksmen, it is deadly.

Of course, at long ranges, it will be n question whether the execntion done will pay for ammnnition spent.

Lixperiments have been made by Major East firing at $a$ particnlar spot from the reverse slope of $a$ hill. $\Lambda$ couple of pegs in line on the brow, and a man with a telescope to signal tho result of shots, being all that is necessary to carry this out in a rongh and rendy fashion.

A bridge or defile where the ground was favourable inight be lield by an unseen gun in this manner.

A range-finder should always be carried with the gan.

'Tho Mekometre, though requiring two observers I belicrc, can determine ranges with only 5 yds. crror up to 3,000 yds.

\section{Sights.}

I advocato tho introduction of orthoptic sights such as have betn adopted by Major Fasst, lst V.B. Hants Regiment, made by 1lessrs. Rigby, I belicve, and proving most satisfactory.

'T'elescopic sights might also be carried with advantnge. 


\section{E. Shielt.}

The shield should be as light as possible, but big onough to cover the firer and strong enough to withstand the heaviest small arm brllet.

A steel shicld of $\frac{3}{8}$-in. thickness will answer this parpose.

There is no doubt that the average man will shoot better when he is safe, or thinks that he is safe, than when cxposed, and a gun with a shield could do a lot of work under fire where an unprotected gun could not lire.

$\Lambda$ gainst this, of course, comes the question of weight and whether the adrantage of a slicld compensates for the extra strain on the horses. JIsself, I think it does.

The officers who worked the Maxim in Mashonaland are all in farour of shiclds.

\section{Personsel.}

\section{a. Gun Detackiment.}

Jany are in farour of forning machine-gun detachinents into separate units.

How far this might answer I cannot say, but at present the regimental system is far more likely to be adopted because it is the most cennomical.

It is rery improbable just now that money will be direrted from other military objects, to establish machine-gun batteries or troops.

For the present, then, I confine myself to the regimental system, which I think can work rery well.

I should like to see three or four machine-guns at least to each caralrs brigade. An oficer, a sergeant, and two men to cach gun.

An experienced N.C.O. and two men with the spare ammunition, which should be carried in a similar manner to the gun.

Sconts should be permanentls told off, botl for the gun and spare ammunition.

When sereral gaus nccompany a brigade, an officer should be told off in charge of them, lest they should all be on one lank and in cach other's way, but a wide latitude as to morements and position must alway's be conceded to indisidual gun commanders.

\section{B. Scouts.}

And now we come to a subject that has not been touched upon so far as I can learn in previous discussions. I refer to scouts.

As with cavalry so with machine guns, the great cliance of success is in surprise, and the chicf risk of failure ljes in being surprised. It is therefore of the utmost importance to hare good scouts, four at least for each gun and two for each ammunition cart.

Caralry leaders are saturally adverse to reakening their squadrons, but $I$ ask you, is it not worth while to take a man out of the rear rubl of cach squadrou, rather than to cripple the whole offensire adran- 
tage of a weapon which, if properly handled, may decimate a whole brigade?

Though it would bo folly to gallop blindly forward, in an unknown country, without scouts, for ground or enemy, it is by pusting forward, not foolishly but boldly, that the gun will make its name.

\section{\%. L'scort.}

Except under certain conditions an escort is a great advantage. It makes a man bold; the knowledge that it will follow and look after the detachment takes awny half the anxiety of the machine.gun commandei.

Without an escort he has to be erer looking round.
Where is the main body?
What is their object?
How can we get there?
Shall wo bo in the way?

are questions that constantly crop up, and though, of course, they must be borne in mind, they should not be allowed to bar the road to enterprise, and a fiold troop, as escort, would solve the question.

Again, the presence of a troop will tend to keep the enemy's cavalry from scattering, and so offer a better target to the gun; this would also apply to infantry, besides preventing the risk of capture from single horsemen galloping in from opposite directions.

Un occasions, when the escort is not required, it could rejoin its squiadron.

\section{Foletgas Progress.}

The following notes I have obtained from foreign military journals :-

In Switzerland there is to be a Mitrailleuse section incorporated in each caraliey regiment consisting of-

1 officer,

1 sergeant,

1 arinourer scrgeant,

3 corporals,

12 men,

2 drivers,

4 horses to draw the ammunition wagon on which the gans are carried on the march;

19 riding horses;

i pack-saddle horses, i.e., 3 for the guns and 3 for the ammunition, the latter carrying 2,000 rounds apiece.

These pack-horses are led by mounted men, who have a stick instead of a leading-rein to prevent their knees being crusbed by ammunition boxes or gun.

They are never to be used singly but to support one another.

Before taking the field the gun commander will obtain his chief's instructious, and will conform to the best of his ability. 
The gun letachment will, as $n$ rule, follow in the rear of tho regiment, bit in the attack will take up a position in rear that the caraliy, if beaten, may rally round them. (While we exanine these tactics we must remeuber the monntainous nature of the country.)

'I 'hese guns will bo most useful in enalsling cavalry to hold an cxtensire line of front along a river or mountain range, a few mnchine guns being placed at the points of passage accompanied by wenk caralry detachments quite independent of the remininer of the covalry.

At night machine-gruns will bo allotted to ontposts nnd pickets.

My authority proceds to sas that no caralry leader is to bo influcneed by the machinc-guns, nor is a single trooper's life to be sacrificed for them.

They are to be looked upou only as a welcome auxiliay to cavalry, nerer as the principal arm.

Whenever it is uccessary, in order to rescue troops, the machine guns are to be sacrificed.

'The moment that caralry lins to corer machine-guns it censes to be cervalys.

There are 24 Mitrailleuses or Maxims required for the Swiss cnralny, and 8 wngons.

The Maxim is carricel with the tripod on one horse and 2,000 rounds on another, its calibre is $7.5 \mathrm{~m} . \mathrm{m}$. or 0.295 bore.

8,000 rounds are carried in the wagon for erery gun.

10,000 l. lias been roted for this purpose, 4,0002 . of which is to be spent this year.

Tho Austrinns, though they lnare not as jet adopted machine guns for field service, admit the necessity of supporting cavalry regiwents witle infontry fire, since in their last mancourres, 1893, they attached two battalions of rithes to ench caraly division, which, in spite of brilliant marching, necessitated to some degrec the subordination of the movements of the cavnliry to the riflemen.

I may montion that one battilion marched 67 miles in two dass, and only 11 men fell out.

\section{Coxchosion.}

In all the abore suggestions I would ask you to benr in mind that I claim nothing for theors; practice and cxperienco are alone the true and proper tests, and anless experiments are made all argument is in raill.

To sum up the whole mattei, whether the grn is carried on horseback or on whecls, whether tho detachments belong to x'egiments or are a unit of themselves, the same tactics will apply; and rapidity of morconent is the great desidentum.

Tell the gun comminder the general idea, give line as fiec a hand as possible, and I predict that these guns, so far from being an inpediment, will be a welcome aid to caralry. They are suitable aliko for attack and defence, a uscful auxiliary to every arm, and will prove thenselves of value hitherto undreamt of. 
- $A$ s the improrement in modern finenrms continues, so does the importance of supportine our cavaly with fire increase.

Here is a chanco of carrying, so to speak, a battalion in our pocket.

We have proved that it can trarel, we know that it can shoot. It is but a few wecks ago that it sared a British column from defeat. One of the enemy has described its effect. In his own words ho sass, "It mowed us down." What is there to prevent these ominous words from being applied to the battles of the future?

IIajor BEsccussr, 20th Hussars : We lare listened rith great interest to the adrantages of machine-guns with caralry, but I would ask carnlrymen to be carcful in accepting maclinc-guns as part of their equipwent too hastils. I am touching a delicate point when I refer to mounted infantry, but I think that arguments hare been raiscd agidint the present system, by oflicers commanding buttalions, becausc their best men aro taken from the battalion. The Caralry Rergulations lay dorn that 60 nen per curalrs regiment should bo trained for mehine-guns. As a caralryman I rould like to sce the all-important duty of scoutiug proctised nnd perfected (if possible), which rould be a considerable gain to our caralry. Our gallant lecturer cnumerates the diflicultics of the oficer coumunding the fun deincliment, by the circumstances he has to consider-without scouts-riz. Whlace is the main body? What is their object? IIow can we get there? Shall ve bo in the way? Those are the anrietics of the offecr commanding tho machine-rgum. Those allucuting the machine-gun worked by curalrymen must not forget that the anxicties of the brighdicr are as councrated abore vith innumerable additions, and rould not these auxictics be lessened if he was amare that there wero in the runks of the regiment 50 good wen trained to scouting and how to report, than that he had 50 men in exch regiment trained to the use of the machine-gun? I am an adrocate for, and do not wish to say a rord against machine-fons working with caralry, prorided they aro worked by proper men and rewain in their proper places. Xet us follow the Ilstone Manocurres. Ciptain Anstruther Thomson is slire to tell us the whole story of the extrnordinary deeds he performed, and thero is no doubt that great decds can be performed by muchine-guns if opportunities occur. 'Tlic all-important point is find the opportuuities. I think on sereril occesions the machine-guns would lare been captured or disabled had it been reality. Duriug tho manourres I obserred that re did not flay the fame with machinc-guns, because, for ms part, thes scemed too insignifieant, and I do not think anjone really knows horr many or how few men are required to capture an unsupported machine-gun. Our lecturer refers to a Nordenfelt haring becn captured by two or threc cletnched nen, I think the Mraxim might lare becn captured in tho same zunner on screral occasions.

Colonel Dicksos : It netcr was.

Major Bestcruser: That is quite true, because mo vere doing peaco manourres, but we will fight together and not against one another in war. "Jhe lecturer talks of the amount of dumago done with lis gun, citing instauces of catching caralry sslecp, or unprotected; as I said before, wo want more caralrs training proper before we can go in for machine-gun training. IIad there been proper scouting the gun should nerer liaro been allowed to get so ncar. Captain Anstruther 'Thomson frequently urged his liak of gool scouts, and appealed for escorts at times. Can we sparc men for such dutics when attacking an enems? Ilo also quotes the incident ou the rodd through Audorer Park, when he applied for au cscort of a feld troop, lie got two squadrons. Were the two squadrons sent to support lim, or was ho sent to support the two squadrons? If tho latter, the machinc-gun was Assisting cerralrs in carrying out its functions as caralrs proper. Would it not bo better if, instead of dashing about on an independent duty, the machine-guv remained in a position whero the brigadicr could send for it und send it to the wost deadly position, which position through the infornation gained by scouting Ec., should be known to the brigadier better than anyoue elese? Eventually we find 
Captain Thomson learing the caralrs in his independent róie, and mixing with the infontrs and mounted infantry, which is the right place for the machine-gun. Perhaps there are not many who will back me up on that point. Hare re auy experience of the effect of machine-guns on moving targets? We hare heard is grcat deal of the deadly effect of inachine-guns on statiousary or elow moring unasses, but on rapidly noring targets it would be different. What damage would a machinegun inflict on a cliarging regiment of caralry in front of it, especially if the target had an element of danger to the firer. Cuptain Anstruther Thomson claims to hare destroged a whole battery of artillers at one time, which is rather rough nu the artillery; and at another time he mentions the destruction of a whole brigade of caralry fith bis gun. If a machine-gun is really so deadly, so destructirc, hare them ererywhere, and manmed by the best men to be found augwhere. I would like to raise the question whether the machine-gun if used with caralsy and worked by caralry, is in its proper place, riz., "in the front line," when caralry are charging. Also whetler the time expended in training men as machine-gunners would not be better spent working with their own regiments learning the inmumerable dutics of caralry proper.

Captain EAST: I know nothing about earalrs whatercr, but I liare lad a little experience with the Jaxim gun, not with the caralry carriage but with the infantry carriage, and there are some ferr words I might say. With regard to the question of moring targets, $I$ hare shot at a moving target. We fired at a barrel going along with an 8-knot current at an unknown range off Warden Point. The D.R.F. was to gire the ranges. At the beginning I said "I Iet us see if the gun cannot find the range for itself." The result was I found we could pick up the range with the gun quite as fust as the range fincler could gire it to us, the ranges being between 1,100 and $1,400 \mathrm{yds}$. It is the simplest thing in the world to hit $a$ moving target; Jou hare onls to las your gun well in front of it, and then the target goes through the stream of bullets. There is no question ubout making good shots, and judging so many degrecs of right or left defection; you simply get the strenin of bullets in front, let the gun run, and jour target has to go through it. You cannot miss; it is alwost impossible in that way, prorided jou can sco where Jour bullets strike. That is the one thing about this gun, and the one great adrantage, I take it, that this Jarim has orer all other guns that I lare ecen, that it nakes such a close pattern, to use a sporting gun phrase; and rou really can ece the strike of the bullets at ranges where you cannot see cither a single bullet or recognisc the ground beaten by controlled fre, that is, rollers. Say at 1,000 jds., 60 per cent. of your rolley will be in a space $100 \mathrm{Jds}$. long by $10 \mathrm{Jds}$. wide, the whole rolley will corer $200 \mathrm{sds}$. long, but the bullets from the Maxim at 1,000.jds. will be within $8 \mathrm{ft}$. in breadth and $27 \mathrm{jels}$. in length; jou will ece them casily drop. ping in as they do at the rate of orer 600 a minute, 11 a second. It rers much depends upon the state of the ground and the stato of the atmosphere, but you hare a rery mich better chance with that weapon of seeing where your bullets fall, and jou can regulate jour firo bj that. Fou do not want to tale n fresl sight. 'The look-out man will say, "You are a little too low or too high," and you get jour eleration in that way. With regard to indirect firing, I rather expected to hear some one say it cannot bo done. I only tried it on one occasion; I tried two experiments, Colonel Hale saw what happened, and the amount of time it took to get the range. I did not use at that time any instrument for the purpose of getting thic range or the vertical eleration. It was simply a casc of tipping the bullets orer the crest of the hill, and sceing where they were falling. I was watching tho fire; it began low, and I wared my handkerchief up until thes got on the target. It was a rery simple matter. Then I may mention the question of mounting, I am conrinced that the mountings of this gun should be made as light as possible. I went to the mancurres, of which we have heard, and looked on a good deal; in fact, $I$ was really hunting the machine-guns all the time, but $I$ was trying to study the infantry not the caralry gun. As a matter of fact, I ultimately found myself hunting the casalrs guns for this reason: the weight of mounting of the infantry gun was ouch that on those contours that we had at Idstone the infantry gun could not get up at all; it was always in the rear. The Nordenfelt gun carriage weighs $10 \mathrm{crt}$., and the ecrice Maxim gun 9 ckt. If jou come to a big liedge you canust 
fet thesc lieary carriages orer, and we got some plaecs were the slopes were one in four and one in three, there thes simply could not get ul at all. 'Then again the serrice carriage ia londed up with 4,000 rounds of ammunition. It appears to me sou want a rery much lighter load. No doubt we should like to liave $\$, 000$ rounds with us on the gun, and wo should like to hare 10,000, but we had better get with 2,000 rounds where we can use it, nnd trust to more ammunition coming up before we hara run out, than not get into action at all. I attended tho manowurres near Petersficlal witl the infantry carriage that I lase carrying 3,000 rounds, and thero the whole weight is $11 \mathrm{cxt}$. It is a little mininture limber and gun carringe, but it splits into two parts of 5 and 6 cwt. respectirels, and there is all the differenco in the world between getting one of 5 and one of 6 crt. orcr a hedge and getting $10 \mathrm{cwt}$. orer in one luinp. Fou cannot get the $10 \mathrm{crt}$. on the one pair of whecls orer at all. On one occasion I got into a wood, and we had either to go through or round; with ins little light cnrri:Ige and 12 nen I scmnbled througli the wood and got to the other side, and I lind some rers good fun afterwards. The Nordenfelt that was wilh me, and started from the same place in the wood, nerer came into action for 45 minutes after I left it. It came in just as the ccaso fro sounded. It was so leary that it had to go back, down the roud, and all round tlie wood, it could not possibly get througl. I am glad thut Captnin Thomson has mentioned the tripod. It is absolutely necessnry, whaterer lind of mounting sou are on, to carry a tripod. Of course it does not so much apply to caralry, but eren caralrs will ocengioally find tlemsclres where ties will want to do a little rillage defence, and then the tripod comes in. You can get it anywlicre you like, up a clurch towcr, and in all sorts of places where no whecled carriage could go by any possibility. It only weighs 47 lbs., and it is n most important thing to lare. From my little experience I must thoroughly concur with Captain Thozson in crersthing that he has said, and really ar.ust of the remarks made with regird to caralry guns rould appls, with but slight modilication, to the infurtry rorking of these guns as vell. ${ }^{\prime}$

JIajor G. Srove: The lectures las so necurately expressed iny own ricws on the subject that I hase rery little to sas. He las alluded to the formatiou or organization of nachine-gun scetions regimentally, that is to sas, in conncetion mitl the reginent or battalion as opposed to the sssteu which eone lisre adrocated of making them into batteries or troops, or wluterer rou like to call them, in fact, making then independent units. I thint the conditions now aro somewliat changed to what thes nere four or fire jears ago. Four or fire sears ago the machinc-gun was essentially nobods's child, and as we are a rery conserratire nation, we naturally look rery euspiciously at any new veapon. Four or fire years ago the machine-gun was not likely to get uscl to much atrantage so long as it was attached to regiments of iafantry or caralry, for the simple rcason that the coinnander of a caralrs regiment rould, a Mlajor Beauclanip has alreads said, look somewhat jealously at it, eajing that his best men were being taken to manipulate the gung, and so on. Possibly a cimilar fecling might exist in infintry For this resson I think the ricms expressed somo jears ago as to the adrisability of forcing the niachine-gun sections into separsto units were rery sound, but since the subject has been more karmls taken up by mans ofliecrs, tlie lecturer, and others, who hare gone into it rers keenly, judging not by theory but by practical proof of what the gun can do when properls handled by men mlio understand its praclical working; the conditions, I think, liare been rather changed, and I an melined to gire up the riew I once held, and think perbapa it is better that the

1 The infanter gun cquipment I use and adrocate consists of gun on field carriage, with shield carrying 1,000 rounds. Ammunition, weight 5 cwt. Limber drana by cob carrsing 2,000 rounds, rilles, toola, \&c., aud to which the gua csrringe is limbered up on the linc of route, weight $6 \mathrm{cwt}$. Ammunition cart drann by horse, carrjing tripod, entrenching tools, foragc, de., and 7,000 rounds ammitnition, with limber look in rear, to which gua carriago can hook on if neceskary. l'otal weight $12 \mathrm{crt}$. Special arrangements are made for conresance of ammunition from one to the other bs hand in action.

VOL. XXXYIII. 
gun should remain part and parcel of the reriment or battalion. Then, with regard to another point, tho lecturer say 3 he thinks we should hare at lenst threc or four guns will cach cavalry brigatc. Our ficld force for seivico abroad, hy which I mean the spccial ficld force to be cmployer in our colonial experlitions, includes a caralry brigade with ono regiment haring a machinc-gun ecetion as well as a company of mounted infantry haring also onc machine-gun scction. I am not including the infantry machinc-gun section, as that belongs to tho infantry division. I think this proportion is rery small, and as it is clcar that the nuthorities who were responsible for draning up the organization of our field forec must hare felt at the time that thes required to treat it in a somewhat exceptional manner no regirds the caralry brigale, in ricw of the fact that two batterics of horse artillers instead of one hare been allotted to it, I think that further experience of what the machine-gun can do with earalry might lead them to sec the adrantage of haring perhaps one machine-gun scetion with each caralry regiment, that is, three scetions for a brigade, these to be brigaded together when necessary in the same way as the regiments thensclres, sometimes with the whole brigade and sometimes separatcly. This sugrestion refers only to the organization of the cavalry brigado allotted to the field force for scrvico abrode. ${ }^{1}$

Colonel J. 13. B. Dicksox : I had no iutention of eaying anything this afternoon, because I anree with almost erergthing the lecturcr bas said. On one point. I do not agree. He sass he would like to hisve an eacort. Well, erery little party jou send out would liko to lare an cscort-ercrybody wants in escort. I haro Lad a little experienco on different ocensions wilh caralry brigales and caralry regiments, and my opinion is that you should scud out as few aud as good scouts as possible; cscorts should be rery seldom giren, even to horse artillers. Of course, when jou send batteries array to some distance they must hare an cseort, but, as a rule, the nearest body of caralry to where the battery cr inachinc-gun is placed is generally a suffieient protection. Major Beauchamp mado an obscrva. tion to the effect ilsat he was prejudiced against machine-ghtns for caralry, for the rery natural reason that he does not like parting with his men; but he seems under the impression that it is necessary to hare $50 \mathrm{mcn}$. I think firo men is the limit.

Captain Thoysos: Three men I nsk for.

Colocel 1)rcksos: And scouts. I should gire the three men, and I should gire possibly firc men, but certainly not more than that. The gun coumander would hare to mako the best of the fire men. I should also be rather afraid of his scouting too much. I should like to sce the guns ncar the brigarle, and all the scouting done by tho brigade. I think, of course, the machinc-guns should hare a perfectly free liand, so as to help the caralry as much as possible, but that tho caralry should not subordinate itself to the guns. Jeference has been malle to tho two squadrons that went to the lecturer's assistance when he applied, I think it ras fur a ficld troop as cscort. During the manocurres quoted I think this wis tho onls occasion when two squadrons acted of their owu uccord. Is I lad frequently eaid, " Ferer mind indiridual squadrons, but lesre them alone; wo want to act as a brigade." They, howerer, snr what they thought a good opportunity, but which, I am sorry to say, turned out unfortunately for them.

Colonel Lorsdale HALr: The Council, at my suggestion, wrote to all the commanding officers of caralry regiments who had been engaged in theso mancurres, in the liope that some of them or their officers rould como and take part in this discussion. According to the lecturer and military historian of Colonel Dickson's caralry brigade at these mancuvres, Coloncl I)ickson's machinc.gun carticd crerything before it, and so far as I saw it, it did so. But there aro alwass tro sides to a question, and it would hare been well to hare had the opinion of Colonel Wardrol

1 The experienco of the majority of our small wars tends to show that in nany caecs there should bo an unusual proportion of cavalry, mounted infuntry, and nounted machine-gun sections. The Boer War is, perhaps, the most striking instance of the uneuitability of infantry for the operations which had to be undertaken. 
as to what the other brigade thought about the effect prodaced by the hostile machine-gun. I mas rather surprised at soino of the remarks that fell from 3 Iajor $^{2}$ Beauchamp. Tho lecturer diel not exactly claim that that caralry brigaclo were swept away on the conroy ding. I should like to hare asted Colonel Wardrop how kas it that he went in front of this machine-gun at $800 \mathrm{sds}$ and took no notice of it at all? As that brigade acted, they must absolutely hare suffered most cnormous loss, as Major Beauchaunp says you do not look after it: 'There is this little machinegun, a sort of caralry lea, lopping abont from one place to another, as Captain Thomson clid make it hop about most admirably during the whole of the mancurres. It was here, there, and crerswhere, and gone before jou could catch it. That is just the point of the machine-gun. Of that ciralry squadron that the gun caunht 200 yds. a ras, AIajor Bcauchamp says that if the scouting had been properly done, it mould not hare happered, but Eomehorr or other from ms rccollection of military history, caralry do not almass scout properly.

Major 3racchuse : Not our cavalry.

Coloncl I opportunities, the opportunitics for the use of machine-guns will be simply innumerable if manourring is anything like war. With regard to escorts, Colonel Dickson has spoken against them, and, if I were Captain Thomson, I would leave the qucstion of escorts to itself. I am a firm belieser in the machine-guns, and I an perfectis certain the first time thes are used on scrrice with regiments of caralry the caralry commanders will beliere in them too, and, ratker than sacrifice tlecir machine-guns, if thes think the machine-gun is in danger they will gire the cscort. The cscort question will ecttle itself simply by the experience of war. Major East has referred to ne with regard to whint took place. Major E:sst is unknown, perlings, to eomo gentlomen here prescnt, and I mar say he has a prirate range of his own, and a prirate Maxim gun. Ie kindly invited no to his loome, and I went down under the impression that a machine.gun was a weapon which was constantly jamming and liable to get uscless. He showed me the mechanism of the gun, and the jamming, I am informed, happeng because when the machineguns are issucd to our troops it is forbiclden to allow the barrel to be remored from the water casing; the regiments are nerer allowed to do that. The consequence is, the glands on which the barrel works get stiff and linrd, and after they are kept six months in store the gun jams. 3[ajor Fast laughed at the ideas of the gun erer jamming. ITe took tho barrel out in my presence, nnd in about 10 minutes put it back again. 'The failures of tho gun which occur at mintecurres arise from the gun not being properly taben carc of, and the men in clargo not being properly instructed in it. I can corrobornte rilat Xajor Fast siss about firing at unseen objects. Fou can get behind a hill, and, as ho sass, anil as $I$ saw, sour render the bridge almost untenable by this flea hopping about, and pouring this stream of bullets upon the bridge.

Captain Axstretner Thousox (in reply): I think almost all the questions hare practically been answered for me. Mrjor Heauchamp speaks of 50 men being trained to the machine-gun as if the 50 men would be taken away from the caralry work of the regiment. But this was not what $I$ meant. I know in the book it does sas that fire oficers nnd 50 men should be trained. I think that is rers right, but it does not entail that these 50 incn should bo taken away from their regiment. Now I only ask for thrco unen to rork my gun. I nsk for ecouts; but the scouting is all-important for caralry as wcll as for macline-guns, and scouts may just as well bo emplojed iu ecouting for a gun as for their own body. With regard to mentioning the capture of the enemy's Nordenfelt, it is a detail, and an insignificant one. I merely mentioned it to point ont what ean be done if jou hare not got scouts. As a matter of fact, all the scouts, the escort, or the eereral men who accompanied the Nordenfelt left it for some reaeon, and our hussars popped down upon it when it was unprotected and unwatehed. With regard to the shooting of tho brigade at $800 \mathrm{Jds}$. at a walk, I only mentioned it as an instance of what possibly, most improbably no doubt, might happen in war. I take no creclit for what the Irarim did. There happened to be opportunities, and I made tho most of then as be:t I might. I hare no doubt, if a brigade was within 800 jels. of a gun properly scrred at a walk, it would be annihilated. Jajor Stone, I think, 
requires no nnswer, as he agrecs with me. With regard to Coloncl Dickson, of course, I take the view of the man with the gun; Colonel Dickson takes the riew of the brigadier, and, of course, I bow to his rien. With regard to Colonel Irale, I now know that it was rery wicked of me to leare tho caralrs, and I offered an apologs for it jou will nolice. The fact mas, I was enticed from one position to another holly cngaged witl the encary. There were caralrs in front of me. I did not know where the rest of the encmy's caralry were. I thinght I had them in front of me the whole time, and I left my orn bots of caralry at a halt doing nothing. I eaw opportunities of corer, and I took them. At r.ny rate, the important tling to my mind was to win the rictory, and I beliere we did so.

The Curarmisx (Licutenant-General J. Keith Fraser): Gentlemen, before asking you to give a rote of thanks to the Jecturer I would jike to make a few rcinarks on what lie bas told us and on what some other offiecrs hare said. In the first place, we hare to thank rers much gentlemen who hare taken part in the discussion, some of whom do not belong to the caralry. I think Major East's obserrations are of great value to us as coming from a man who has tested the working of machineguns so thoroughly. I am in a neutral position with regard to the last mancurres, berause, although I commanded the caralry dirision, the brigades were separated, and therefore I looked on almost as a spectator, and $I$ am not so biased in farour of one side or the nther as naturalls people who take part are. From all I sam of the way the gum was worked, both in 1590 and 1893 , I can only say that if I went on serrice with a brigade or dirision there is nobody I should like to hare in charge of machine-ganz better than our lecturer. Jisersbody who saw him shared my opinion; he was always in the right place, and worked the gun monderfully. Is a caralrs oficer, I am greatly in farour of machine-guns accompanying the cardiry, and I hare the greatest possible opinion of their future. I think the rapidity with which ther can come into action is the main point. Of course, wo should all like to lare the horse artillery guns up, but that is inmossible, cren with lighter aus tlan we hare now. Machine-guns ouglit to go a fast as caralry, nnd they should hare carriages which will get orer erers spot of ground with equal rapidity as the malrs. I am afraid I differ with the lecturcr on ne or tro points. Colonel Dickson has done so also, and I must saj I agrce thoroughly witb Coloncl Dickson, from the caralry commander's point of riew; and not as Captain Thomson looks upon it, riz., from the point of ricw of the offeer in charge of the guns. I do not think thes ought to be independent of caralry. We bare erough branches of tho Serrice already, if not too manj; the less of them the better. We had better stick to our old caralry, infantry, and guns. If we hase these indepen. clent specialist branches I am slrags afraid of their not being at the right moment where we want them. I think the great thing is to hare the machine-guns stiching to their regiments and brigades 23 near as they can. Horse artillery has to go a long way off to take up adranced positions or to go to the flank; it has to go right away, but the machine-gun should stay with the caralry, ready to take part at once in the nction if the caralry are advancing to attack.! With regard to the atinck on the artillery which the lect urer spoke of. It would be effectire, no doubt, as long as there are a good manj men about the guns loading and firing; but I fancy at some future das we shall hiare Q.F. guns, where the men will be behind the gunone man on the trail, another inan firing-tro men or tliree men, and they would be well corered bs the gun, and also, I suppose, by shiclds from musketry firc. I donbt, therefore, whether the machine-guns would haro rery much effect upon artillers. I thint the danger to artillerg is caralry ; I would rather attack artillery with caralrs than with the machine-gun. With regard to infantry and caralry, we know from what we lieard in the late kar the effect has been something marrcllous. This morning I saw the original of a letter that appeared in the "Pall Mall Gizette" of Iast night from Captain Lendr as to the cffects of the gun, in which he described its terrible effects, and stated that the Matabele said that they would "fight us again if me left our MIarims at home." I think there is no doubt, both

1 The machine-gun fire would hare the same effect as case-shot, and would reliere the artillery from the necessity of making use of the latter. 
against cavalry and infantry, its effects will be most marrcllous as a weapon of offenec, but the caralry will hare the adrantage of being able to more out of its firc rery quickly. I roust say a rord about Captain Lcnely. I dnresuy a good jonany of us know Captain Lendy's father, and I think we all must hare hearl with the greatest regret of the death of his two gallant sons, one in Wrest Africa and one in East Africa, who both died by unfortunate accidents, both being most dietinguiahed men who had alrealy made their zisurk. As to escort and scouts, the lenand is much too often made for an escort, or to send some more scouts. If sou only knew how weak our caralry is on all occazions, how weak our squacirons are for fortign service! A squadron in England is only two-thirds the strength of any squadron in Europe. I know it is a great compliinent to us, and I hare no doube the people who franed that Regulation meant it as a great compliment to Finglishmen, but if you begin to take awar escorts and scouts and all theso kind of things when foreign armics are prorided with separate sections, troops, and half squadrons for this purpose we shall be in great difficults. Erers regiment abroad has a quarter of the squadron used for this purpose, and kept separate. If we lare to take them from the ranks you will couse dorn to haring noboly at all with your squadron. If you send a troop here and a troop there you end by haring notling, and we cannot aflord that. I am all for sending out as few scouts as jossible. I nm sure a few scouts are of much more serrice than many scouts-5ou cannot baro too fek. I think the guns remaining near the caralry, and trustiog to the caralry scouts do not want any special scouts. Of course, if jou scnd then. away sou must liare one or two. If there are only three men with a gun possibly. Jou can send a ecout or two, but otherwise there should be no eseorts and no scouts. I lial a letter from Mrajor Baden-Powell, rhose name has becu liere mentioned. I think most of the points ho males hare been already raised, but ho has taken great interest in the machine-guns, in harnessing the liorses, putting threc horses abrenst, se., and there are one or two points he wishes me to mention. He thinks there is a habit, from what he has scen, of looking upon the eafety of a macline-gun as " matter of honour, and that you rnust stick to it and not lose it on any account. I think that iden has gone out, eren with the horse artillers; they are now quitc willing to stand by their guns in action to the last, and lose the guns if necessary. It is not a point of lonour now not to lose the gun, but it is a point of honour to do the best you can to the last, and eren to lose your gun. II points out, further, that he thinks that machine-guns ought to be as low down as the axle; that a tripod sliould aliwass be carricd; that the gun should be ensily detachable to be plaed on it. He also thinks the idea that horses can go rapidly over broken ground and crery sort of ground drawing 6 cwt. is wrong. He thinks it should be 5 cwt. at the outside, and that 4 cwt. is about what is right. It depends a great deal upon the lorses; taking an arerage 4 cwt. is suffeient, and $I$ fully agree with lim. He also sags he has heard Mr. Sclous attach the greatest possible ralue to what the machine-gun has done in the late campaign. JIs own opinion is that what we want for the caralry are liglit Q.F. guns, 6-prs. or 9-prz., that can keep up with us and go crerywhere, and get into action quickly. At the same time, I am all for haring a machine-gun to ererg regiment of caralry; I think it mould be of the greatest postible ralie. I'Le lecturer sass le would hare it on the flank. I would lare it behind the centre, or whereser it could get ont quickly when it was wauted to the frout or cither flank. dlthough there are greater dingers, as cverybody sees, to cavalry owing to the improrements in firearms, my own idea is that the improre. ment will giro us also immensely increased power. I think we shall hare a great adrautage myself orer other arms. We can more anap from fire, wo can male lauk morements rapidls, whereas the infantry, when they come under fire, cannot get out of it quickly. I think with these guns our day is getting better and better. I hare only now to ask rou to give a rote of thanks to the lecturer. I am sure we ure all greatly obliged to him, and I think the number of officers present shows the interest that is taken in this subject. 


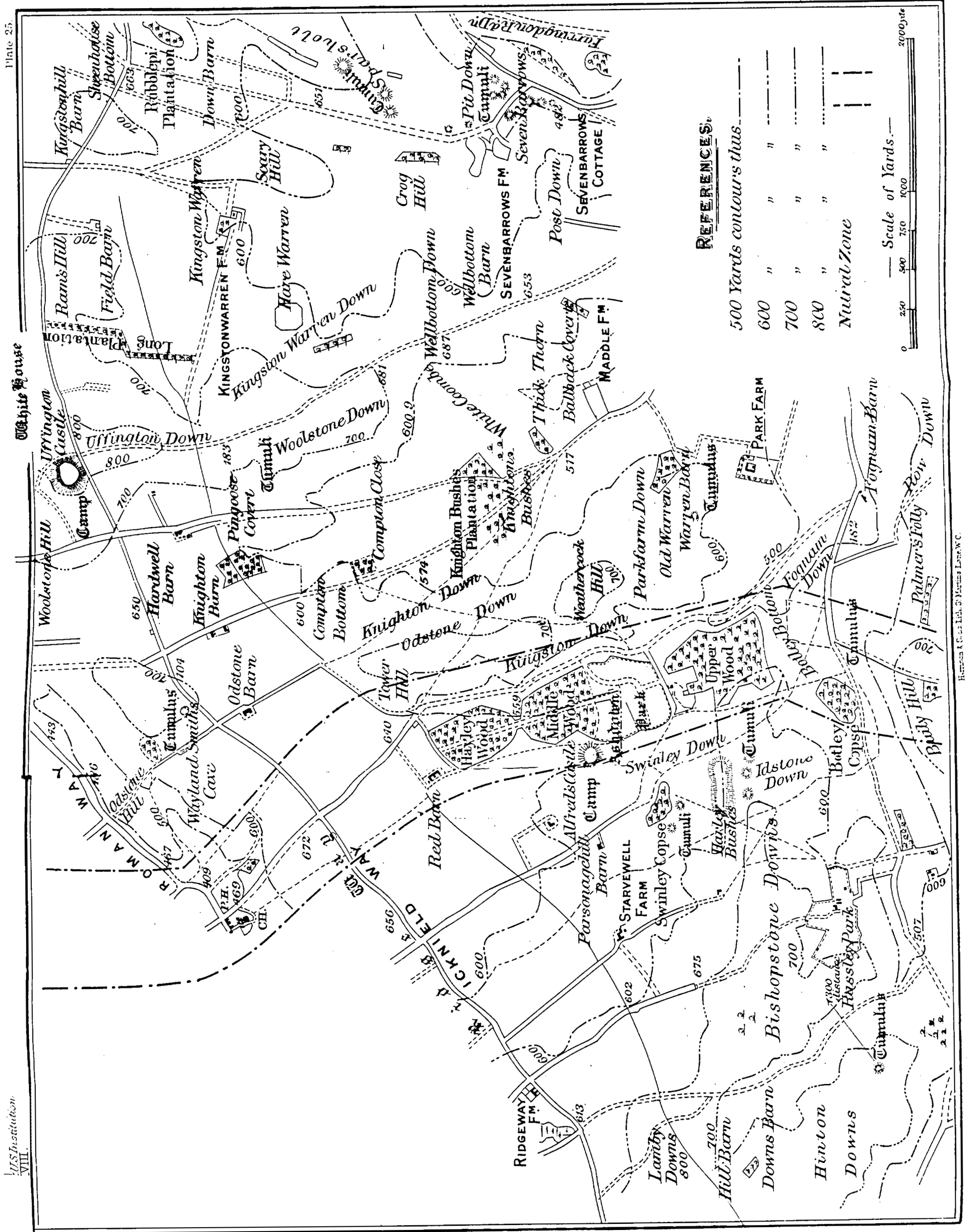

